\title{
ÆLFRIC'S EXPRESSIONS FOR SHAME AND GUILT: A STUDY IN INTRA-WRITER CONCEPTUAL VARIATION
}

\author{
JAVIER E. DÍAZ-VERA ${ }^{1}$
}

\begin{abstract}
This research focuses on the analysis of onomasiological variation in Old English texts written by Ælfric; more specifically, I am interested in the study of the different motifs that shape the linguistic expressions of shame and guilt used by this Anglo-Saxon monk across different textual genres. Through the fine-grained analysis of the whole set of shame and guilt expressions recorded in the entire corpus of Ælfrician texts, a network of literal and figurative conceptualizations for each emotion is proposed here. Based on this network, I have reconstructed and analysed patterns of conceptual variation in Ælfric's English in order to show the existing tension between literal, metonymic and metaphoric expressions for these two emotions. As shall be seen here, the introduction in Anglo-Saxon England of Augustinian psychology by Ælfric and other highly educated authors favoured (i) the progressive neglect of the Germanic concept of shame and guilt as instruments of social control, (ii) the dissemination of new shame-related values, and (iii) the growing use of a new set of embodied conceptualizations for the two emotions under scrutiny here, most of which have become common figurative expressions of shame and guilt in later varieties of English. The new expressions (e.g., SHAME IS SOMETHING COVERING A PERSON, GUILT IS A BURDEN) illustrate the shift towards a progressive embodiment of the new emotional standards brought by Christianization. According to these standards, rather than an external judgment or reproach, shame and guilt involve a negative evaluation of oneself.
\end{abstract}

Keywords: Old English; metaphor; metonymy; emotions; shame/guilt.

\section{Introduction: The individual dimension of conceptual variation}

During the last decade, the study of metaphor variation has become one of the primary foci in Cognitive Linguistics (Kövecses 2007; Musolff 2015; Güldenring 2017). It is nowadays widely admitted that the original understanding of

1 Universidad de Castilla-La Mancha; Avda. de Camilo José Cela s/n 13071, Ciudad Real, Spain.JavierEnrique.Diaz@uclm.es 
conceptual metaphors as universal and, consequently, invariable, is highly incongruent with the existing extraordinary variety of metaphorical conceptualizations, not only across different linguistic varieties but also within the same language (Grondelaers \& Geeraerts 2003).

Kövecses (2007: 18) distinguishes two different kinds of dimensions along which metaphors show variation, namely (i) the cross-cultural, and (ii) the withinculture dimensions. Whereas most studies on metaphor variation have focused on the cross-cultural dimension, very few metaphor researchers have turned their attention to the different ways the same concept can be metaphorically expressed by speakers from the same speech community. Within the general within-culture dimension, Kövecses (2007: 21) further distinguishes seven different subdimensions, namely (i) social, (ii) regional, (iii) ethnic, (iv) style, (v) sub-cultural, (vi) diachronic, and (vii) individual. Once again, whereas some of these subdimensions (such as the social, the regional, and the style sub-dimensions) have received most of the attention, some others are still very clearly under-explored.

This is especially true in the case of individual onomasiological conceptual variation, consisting in the study of the individual language user's onomasiological choices in specific usage contexts (Geeraerts 2002: 212). For example, a speaker can refer to a particular referent (for example, an emotion) using either a literal expression or a figurative one. In the second case, speakers will select one specific conceptual mapping, discarding all the other mappings available to them, or even create a brand-new conceptual connection in order to show a very personal view of that emotion as something else. For example, a speaker can express a view of fear as "trembling limbs" (a metonymy based on the mapping FEAR IS PHYSICAL AGITATION), or as "being sick" (a metaphor based on the mapping FEAR IS INSANITY), or even as "smelling something bitter" (a synaesthesia based on the mapping FEAR IS A SMELL). Through their everyday onomasiological preferences, speakers reveal which conceptual connections are more relevant in their personal understanding of that emotion and, by extension, in their own culture.

Based on the above, in this study I will try to analyse individual conceptual variation through the identification and analysis of regular patterns of context usage. In order to interpret these patterns, I will take into account two different sociolinguistic factors, namely, 'textual type' and 'level of translation' (i.e., relation with the Latin original; Kytö 1996), which will help interpret the individual speaker's onomasiological choices, as reflected in a textual corpus.

More specifically, this research will be based on the study of the Old English expressions for two very closely-related emotional experiences, i.e., shame and guilt, as represented in the bulk of surviving Ælfrician texts (Kleist 2001). I am especially interested in the study of the different motifs that shape the linguistic expressions for these two emotions used by the Anglo-Saxon monk across 
different 'textual types' and 'levels of translation' (Kytö 1996). Through the finegrained analysis of the whole set of shame- and guilt-expressions recorded in this corpus, a network of literal and figurative conceptualizations for each emotion will be proposed. On the basis of this network, I will reconstruct and analyse patterns of conceptual variation in Ælfric's English in order to show and to interpret the existing tension between literal, metonymic, and metaphoric expressions for these two emotional experiences.

\section{Corpus description}

The corpus used here consists of 203 Old English texts confidently attributed to Ælfric, with a total of 485,220 words in Old English (plus 25,144 words in Latin). As aforementioned, this study of intra-writer conceptual variation takes into account two basic factors: 'textual type' and 'level of translation'. Firstly, these texts represent seven different 'textual types'; however, the distribution of running words and texts is highly irregular, with a very strong predominance of two main types (i.e., $<$ Homilies $>$ and $<$ Saints' Lives $>$ ) and a clear underrepresentation of the others.

Table 1. Structure of the Ælfrician corpus

\begin{tabular}{l|c|c}
\hline TEXTUAL TYPE & $\mathrm{N}^{\circ}$ OF OE WORDS & $\mathrm{N}^{\circ}$ OF TEXTS \\
\hline HOMILIES & 297,397 & 141 \\
\hline SAINTS' LIVES & 100,087 & 34 \\
\hline RELIGIOUS TREATISE & 49,454 & 17 \\
\hline PREFACE & 3,056 & 4 \\
\hline GLOSSES & 2.363 & 4 \\
\hline GRAMMAR-GLOSSARY & 27,552 & 2 \\
\hline ASTRONOMY & 5.311 & 1 \\
\hline TOTAL & 485,220 & 203 \\
\hline
\end{tabular}

A second factor of linguistic variation is the relationship between an Old English text and the corresponding Latin original. Following the principles outlined by the Helsinki Corpus and its sister corpora, I will indicate the different types of relationship with their Latin originals, illustrated by each Ælfrician text through the use of the following values. Once again, as can be seen in Table 2, these categories are very unevenly represented in the corpus, with an obvious predominance of text written directly in Old English. 
Table 2. Levels of translation from Latin to $\mathrm{OE}$

\begin{tabular}{l|l|c|c}
\hline LABEL & \multicolumn{1}{|c|}{ LEVELS OF TRANSLATION } & $\begin{array}{c}\mathrm{N}^{\circ} \text { OF OE } \\
\text { WORDS }\end{array}$ & $\begin{array}{c}\mathrm{N}^{\circ} \text { OF } \\
\text { TEXTS }\end{array}$ \\
\hline <Lat0> & $\begin{array}{l}\text { Texts written directly in Old English (no } \\
\text { influence from Latin }\end{array}$ & 439,720 & 182 \\
\hline <Lat1> & $\begin{array}{l}\text { Unknown or irrelevant influence from } \\
\text { Latin original }\end{array}$ & 3,893 & 2 \\
\hline$<$ Lat2> & $\begin{array}{l}\text { Relatively high degree of interference from } \\
\text { Latin original }\end{array}$ & 37,438 & 14 \\
\hline$<$ Lat3> & Old English glosses on Latin texts & 4,169 & 5 \\
\hline & TOTAL & 485,220 & 203 \\
\hline
\end{tabular}

3. OE 'shame' and 'guilt': The big picture

The expression of shame and guilt in Old English has been widely analysed by Jorgensen (2012), Díaz-Vera (2014), Díaz-Vera \& Manrique-Antón (2014), Khan, Díaz-Vera \& Monachini (2018), and Khan et al. (in press). Most of these studies use a corpus of reference (known as CÉROE: Corpus for Emotion Research in Old English), which consists of circa 1.5 million running words in Old English, divided into two large sections: prose (100 texts) and poetry (30 texts). ${ }^{2}$ Using this corpus of reference, researchers have analysed the distribution of 21 different Old English expressions for shame and 28 different Old English expressions for guilt across textual types, levels of translation, and historical subperiods.

The set of OE shame-expressions identified in the reference corpus can be divided into two large groups, namely literal expressions and figurative expressions (see Table 3). Within the second group, a variety of source domains have been identified, each one of which highlights a specific aspect of the shame-experience:

Table 3. The Old English vocabulary of SHAME in the reference corpus CÉROE

\begin{tabular}{l|l|l|c|c}
\hline Themes & \multicolumn{1}{|c|}{ OE EXPRESSION } & SEMANTICS & $\mathrm{N}^{\circ}$ & $\mathrm{T}$ \\
\hline SHAME & sceamu, sceand & literal & 265 & 265 \\
\hline SADNESS, DESPAIR & $\bar{a}$ swceman & metonymy & 1 & \\
\hline
\end{tabular}

2 The selection of texts included in the prose sub-corpus used for this research is based on the syntactically-parsed York-Toronto-Helsinki Parsed Corpus of Old English Prose (YCOE 2003), which contains 100 Anglo-Saxon texts classified into sub-periods and textual types. Similarly, the selection of texts in the poetry sub-corpus included in the CÉROE is based on the syntactically parsed York-Helsinki Parsed Corpus of Old English Poetry (YPC 2001), which includes samples from 30 different Anglo-Saxon poems representing a range of dates of composition and authors. 


\begin{tabular}{l|l|l|c|c}
\hline WORRY, FEAR & $\bar{a}$ färan & metonymy & 1 & 2 \\
\hline DISHONOUR, DISGRACE & ārleas, orwirpu & metonymy & 179 & \\
SCORN, HUMILIATION & bysmor, edwit, hux & metonymy & 89 & \\
OFFENCE, DECEIT & fäcen, fracod & metonymy & 51 & \\
NAKEDNESS & sceamu, cewisc, cepsen & metonymy & 5 & \\
WOUND, AMPUTATION & getawian, purhwadan & metonymy & 2 & 326 \\
\hline ROTTENNESS & füllic, lysu & metonymy & 25 & \\
MOTION DOWNWARDS & hienpo & metonymy & 17 & \\
REDNESS IN THE FACE & ärēodian, äblysian & metonymy & 4 & 46 \\
\hline A LIQUID & ofergeotan & metaphor & 1 & 1 \\
\hline TOTAL & & & 640 & \\
\hline
\end{tabular}

As can be seen in Table 3, shame can be figuratively conceptualised in Old English in four different ways: (i) as another emotion (such as SADNESS or FEAR), (ii) as one of the possible causes of shame (as in DISHONOUR, SCORN, OFFENCE, NAKEDNESS, and WOUND), (iii) as one of the embodied effects resulting from shame (as in BAD SMELL, LOWERING A BODY ORGAN or REDNESS IN THE FACE) or, finally, (iv) as a completely unrelated conceptual domain (as in SHAME IS A LIQUID).

As for the 28 Old English guilt expressions analysed in the above studies, nonliteral expressions have been grouped into (i) resultative metonymies (namely DEBT, OPPONENT, and CAPTIVITY) and (ii) metaphors (i.e., DIRTY OBJECT, HIDDEN OBJECT, MIXED SUBSTANCE, and BURDEN; see table 4 below).

Table 4. The Old English vocabulary of GUILT in the CÉROE.

\begin{tabular}{|c|c|c|c|c|}
\hline Themes & OE EXPRESSION & SEMANTICS & $\mathrm{N}^{\mathrm{o}}$ & $\mathrm{T}$ \\
\hline GUILT & eofot & literal & 2 & 2 \\
\hline DEBT & ābicgan, gylt, scyld & metonymy & 492 & \\
\hline OPPONENT & sacu, fāh & metonymy & 11 & \\
\hline CAPTIVITY & $\begin{array}{l}\text { befōn, bindan, begripan, ālysan, } \\
\text { frēo, hwearfian }\end{array}$ & metonymy & 7 & 510 \\
\hline A DIRTY OBJECT & $\begin{array}{l}\text { wammfull, fül; } \quad \bar{a} \text { cloensian, } \\
\bar{a} \text { dìligian, àfeormian, āpwēan }\end{array}$ & metaphor & 52 & \\
\hline A HIDDEN OBJECT & $\begin{array}{l}\text { dīgol; deop, begrīwan; aboere, } \\
\text { èowan }\end{array}$ & metaphor & 9 & \\
\hline A MIXED SUBSTANCE & asceādan, hluttor & metaphor & 5 & \\
\hline A BURDEN & aberan, hēap, hefigian & metaphor & 3 & 69 \\
\hline TOTAL & & & 581 & \\
\hline
\end{tabular}

In terms of the textual distribution of these emotional expressions across the CÉROE corpus, these studies show a series of very relevant findings. Firstly, they 
corroborate the peripheral character of metaphoric expressions in the Old English emotional vocabulary: in fact, literal expressions and, much more frequently, metonymic expressions were preferred by Old English speakers in order to talk about shame or guilt. Further, rather than the physiological effects of each emotion, these metonymies tend to focus on the socially and culturally relevant aspects of shame (loss of reputation, reprobation, mutilation) and guilt (wergild, outlawry, captivity). In the corpus of reference, an overwhelming preference for metonymic expressions highlighting the social causes of shame (as in SHAME IS DISHONOUR, DISGRACE) and guilt (as in A GUILTY PERSON FOR AN INDEBTED PERSON) can be found. Loss of honour is a frequent cause of shame in shameoriented cultures (Constable 1971; Delumeau 1990). Within an 'honour and shame' system, loss of honour happens whenever an individual fails to comply with the collective expectations and obligations assigned to them. In these cultures, shame denotes a descent in esteem by society, and honour denotes an ascent. Based on these findings, it can be argued that embodiment played a "strikingly secondary role in the linguistic expression of these two emotions, as Anglo-Saxon speakers did not start to encode linguistically the physiological model until several centuries after the arrival of Christianity and its new set of moral standards" (Díaz-Vera 2014: 80).

As for their diachronic evolution, these studies show an increased use of expressions indicating an embodied understanding of shame in religious prose, which is especially visible in texts translated from Latin. This increase in the use of resultative metonymies can be interpreted as an indicator of "ongoing changes in the concept of shame, according to which this emotion is not shaped as a public instrument through which the deviant individual is publicly exposed and humiliated, but as a self-induced emotion based on the feeling of personal guilt as the primary mechanism of social control" (Díaz-Vera 2014: 78). Similarly, the metaphorical expressions for guilt identified above, all of which indicate an understanding of this emotion as an external object that can be removed or purified in order to alleviate the guilty person, are more frequent in texts translated from Latin than in texts written directly in Old English, which, as in the case of the resultative metonymies for shame described above, responds to the new moral standards brough to Anglo-Saxon England by Christianization.

\section{4. Ælfrician 'shame'}

Once these two sets of conceptualizations for shame and guilt in the corpus of reference have been identified and described, it is time to analyse the distribution of these and other motifs for these two emotions in the corpus of Ælfrician texts. In order to do so, following the same methodology as for the corpus of reference, 
I have made a list of all the occurrences of shame- and guilt-expressions, which have been classified into themes.

I will start with the analysis of the 12 different expressions of shame used by Ælfric (276 occurrences in all). As can be seen in Table 5, most of the literal and metonymic expressions described for the corpus of reference appear in this corpus. Furthermore, their relative frequency is very similar in both corpora.

Table 5. The Ælfrician vocabulary of SHAME.

\begin{tabular}{|c|c|c|c|c|}
\hline Themes & OE EXPRESSION & SEMANTICS & $\mathrm{N}^{\mathrm{o}}$ & $\mathrm{T}$ \\
\hline SHAME & sceamu, sceand & literal & 98 & 98 \\
\hline SADNESS, DESPAIR & $\bar{a}$ swceman & metonymy & 1 & 1 \\
\hline $\begin{array}{l}\text { DISHONOUR, } \\
\text { DISGRACE }\end{array}$ & ärleas & metonymy & 101 & \\
\hline $\begin{array}{l}\text { SCORN, } \\
\text { HUMILIATION }\end{array}$ & bysmor, edwit, hux & metonymy & 57 & \\
\hline OFFENCE, DECEIT & fäcen, fracod & metonymy & 13 & 171 \\
\hline $\begin{array}{l}\text { ROTTENNESS } \\
\text { MOTION } \\
\text { DOWNWARDS }\end{array}$ & $\begin{array}{l}\text { füllic } \\
\text { hienpo }\end{array}$ & $\begin{array}{l}\text { metonymy } \\
\text { metonymy }\end{array}$ & $\begin{array}{l}4 \\
1\end{array}$ & 5 \\
\hline A LIQUID & ofergeotan & metaphor & 1 & 1 \\
\hline TOTAL & & & 276 & \\
\hline
\end{tabular}

In fact, just like in the corpus of reference, there is a very clear preference in the Ælfrician corpus to conceptualize shame metonymically as one of the social causes of shame (relative frequency of causative metonymies $61.96 \%$, vs $50.93 \%$ in the corpus of reference). Also, literal expressions for shame show very similar frequencies in the two corpora $(41.40 \%$ in the corpus of reference, vs. $35.51 \%$ in the $Æ l$ frician corpus). However, the most relevant differences between these two corpora can be found in the less frequent themes, namely EMOTION IS SADNESS, EMOTION IS RESULT OF EMOTION, and EMOTION IS A LIQUID.

Firstly, the mapping SADNESS FOR ANOTHER EMOTION is represented in the corpus by the OE āswceman 'to be troubled, suffer grief, languish'. This verb, which illustrates the semantic shift from 'mental pain' to 'shame', is used on three different occasions in the whole Old English corpus; whereas two of these occurrences of $\mathrm{OE}$ āswceman 'to feel shame' correspond to Psalter glosses (where it is used to translate L erubescere 'to blush for shame'), its use as a shameexpression in texts written in Old English is reduced to this single occurrence in Ælfric's adaptation of the Old Testament Book of the Maccabees. 
Secondly, the metonymically-based metaphor EMOTION IS A LIQUID is illustrated by the OE ofergeotan 'to pour over, to cover with a liquid', which appears once in Ælfric's Letter to Sigeweard, a work of biblical teaching composed around the year 1005-1006 (Magennis 2005). As in the case of SADNESS FOR ANOTHER EMOTION (OE āswceman), this is the only occurrence of this metaphor in a text written directly in Old English (all its other uses of this denominator for shame correspond to Old English glosses to Latin texts).

1. He mid sceame wearð sona ofergoten, pa pa he oncneow pone Cristes apostol, \& began to fleonne fram his andweardnysse. (ÆLet 4, 223)

He was soon covered with shame when he recognised Christ's apostle, and began to flee from his presence.

This conceptual mapping undoubtedly represents a more psychologised understanding of shame, which highlights the self-evaluative function of this emotion in Christian ethics (Kahil 2017). In this sense, this liquid metaphor, which is strongly connected with the image of covering one's face with tears, ${ }^{3}$ implies not only a self-regarding adverse judgement that one is degraded, but also an awareness that the ashamed person ought not to be in a position where one could be seen by others (Taylor 1985; Knuuttila 2012).

Last but not least, the causative metonymic pattern EMOTION FOR RESULT OF THAT EMOTION, which highlights some of the uncontrollable physical symptoms of shame (such as prostrating one's body downwards or getting red in the face), undergo a dramatic decrease in their relative number of occurrences, from $7.20 \%$ in the corpus of reference to just $1,81 \%$ in the Ælfrician corpus. Differently put, through his onomasiological choices, Ælfric is avoiding in his writings expressions that highlight the physical manifestations of shame, in order to stress the more psychological aspects of this emotion. Furthermore, as the distribution of these shame-expressions shows, Ælfrician texts illustrate a very incipient move from a metonymic understanding of SHAME AS DISHONOUR, DISGRACE (where this emotion was a strong instrument of social control, as corresponds to a shameoriented culture) towards a more personal construction of this emotion, which can be directly related to the Christianization of Britain and the progressive introduction of Augustinian psychology by the Anglo-Saxon intellectual elites (Lockett 2011).

However, as indicated above (see Table 5), in spite of the conceptual innovations described above, the Ælfrician corpus indicates a very strong predominance of shame expressions in the metonymic pattern EMOTION FOR CAUSE OF THAT EMOTION and, more specifically, for terms that highlight the

3 As illustrated by Ælfric's use in the same text of the literal expressions mid wope ofergoten (1. 217, 'covered with weep') and mid tearum ofergoten (1. 229, 'covered with tears'). 
conceptual connection SHAME AS DISHONOUR, DISGRACE. In order to understand the meaning of Ælfric's onomasiological preference for expressions that stress the function of shame as an instrument of social control, a closer look into the patterns of variation of these metonymies across textual types (Table 6) and levels of translation (Table 7) is required.

Table 6. Distribution of shame-expressions in different textual types in the Ælfrician corpus.

\begin{tabular}{l|c|c|c|c|c}
\hline $\begin{array}{l}\text { TEXTUAL } \\
\text { TYPES }\end{array}$ & literal & sadness & cause & result & metaphor \\
\hline HOMILIES & 14 & - & - & - & - \\
\hline SAINTS' LIVES & 73 & 1 & 171 & 5 & - \\
\hline $\begin{array}{l}\text { RELIGIOUS } \\
\text { TREATISE }\end{array}$ & 8 & - & - & - & 1 \\
\hline PREFACE & - & - & - & - & - \\
\hline GLOSSES & 1 & - & - & - & - \\
\hline GRAMMAR & 2 & - & - & - & - \\
\hline ASTRONOMY & - & - & - & - & - \\
\hline TOTAL & 98 & 1 & 171 & 5 & 1 \\
\hline
\end{tabular}

Table 6 illustrates the distribution of five types of shame-denominators across the seven textual types included in the Ælfrician corpus. As can be seen here, whereas most types show a preference for literal shame-expressions, expressions indicating a metonymic understanding of shame are exclusive of one single textual type, namely hagiography. In order to understand the completely irregular distribution of this model of emotion, some of the peculiarities of Ælfric's Lives of Saints must be taken into account. Differently to the other textual types, the stories narrated in these texts take place in the distant past, in a world of pagans inhabited by two types of characters: on the one hand, the first Christian saints (generally of aristocratic descent), who are willing to risk their lives and physical integrity in the name of their religion; on the other side, their persecutors, who use brutal force to inflict shame on their antagonists. As Bremmer (2014: 119120) points out, saints and prosecutors represent two completely irreconcilable visions of shame. On the one hand, prosecutors use physical torture in order to destroy the honour of their victims by shaming them in public; on the other, the saints see these social shaming practices as a means to add to their honour. Differently put, in his Lives of Saints, Ælfric relies on the conceptual connection between SHAME and HONOUR in order to represent the clash between the early Germanic ethos, represented by the world of pagans, and the post-conversion ethics, as illustrated by the Christian saints and their new, moral consciousness. 
Table 7. Distribution of shame-expressions across levels of translation in the Ælfrician corpus.

\begin{tabular}{l|c|c|c|c|c}
\hline $\begin{array}{l}\text { LEVEL OF } \\
\text { TRANSLATION }\end{array}$ & LITERAL & SADNESS & CAUSE & RESULT & METAPHOR \\
\hline$<$ Lat0> & 88 & 1 & 171 & 5 & 1 \\
\hline$<$ Lat1 $>$ & - & - & - & - & - \\
\hline$<$ Lat2 $>$ & 8 & - & - & - & - \\
\hline$<$ Lat3> & 2 & - & - & - & - \\
\hline TOTAL & 98 & 1 & 171 & 5 & 1 \\
\hline
\end{tabular}

Table 7 illustrates the distribution of five types of shame-denominators across four different levels of translation in the Elfrician corpus. Since most of the texts in the corpus (182 out of 203) represent the category <Lat 0$\rangle$, which is clearly overrepresented in the corpus, it is very hard to draw conclusions from this distribution. However, very interestingly, it should be noted here that all the metonymic and metaphoric shame expressions used by Ælfric are found in texts written directly in Old English, so that translated and glossed texts invariably resort to literal expressions (represented by OE sceamu and OE sceand), even in those cases where the Latin original uses a figurative expression. In this sense, this translation strategy can be considered an example of the conversion of metaphor to sense, which, according to Newmark (1998: 108-109) is sometimes required when the metaphor in the source language does not exist in the target language.

\section{5. Ælfrician 'guilt'}

I will now proceed to analyse the 14 different expressions of guilt used by Ælfric (327 occurrences in all; see Table 8). By comparing Table 8 to Table 4, it can be easily seen that some of the guilt-expressions recorded in the corpus of reference are completely absent from the Ælfrician corpus: this is the case of OE eofot, OE äbicgan, and $\mathrm{OE}$ cebcere, all of which were nearly exclusively used in AngloSaxon legal texts.

Table 8. The Ælfrician vocabulary of GUILT.

\begin{tabular}{|c|c|c|c|c|}
\hline THEMES & OE EXPRESSION & SEMANTICS & $\mathrm{N}^{\circ}$ & $\mathrm{T}$ \\
\hline DEBT & gylt, scyld & metonymy & 279 & \\
\hline CAPTIVITY & befōn, bindan, begripan & metonymy & 8 & 287 \\
\hline A DIRTY OBJECT & $\begin{array}{l}\text { àclcensian, àdìligia, âfeormian, } \\
\bar{a} p w \bar{e} a n\end{array}$ & metaphor & 22 & \\
\hline A HIDDEN OBJECT & dīgol, deop, begrīwan & metaphor & 10 & \\
\hline
\end{tabular}




\begin{tabular}{l|l|l|c|c}
\hline A MIXED SUBSTANCE & hluttor & metaphor & 6 & \\
A BURDEN & aberan & metaphor & 2 & 40 \\
\hline TOTAL & & & 327 & \\
\hline
\end{tabular}

More importantly, one of the metonymies identified in the corpus of reference, i.e., A GUILTY PERSON FOR AN OPPONENT, is not recorded in Ælfric's texts. This model of guilt implies an understanding of the guilty person as an enemy, as someone that should be avoided by the other members of the community. Within this framework, the accused person is conceptualized as an outlaw, someone outside civil society. This idea is very clearly illustrated by Anglo-Saxon laws, which dictate that if a murderer cannot compensate the victim's family with the payment of the wergild, they will be put outside the law and deprived of its benefits and protection (Díaz-Vera 2014: 74).

Just like in the corpus of reference, the Ælfrician corpus shows an overwhelming preference for a metonymic understanding of guilt as a BEING INDEBTED (307 occurrences) or as BEING HELD CAPTIVE (7 occurrences). Whereas the first source domain is very widely distributed in the corpus of Old English texts, the use of the latter as a denominator of guilt is apparently limited to texts written by Ælfric. Differently to the pattern A GUILTY PERSON FOR AN OPPONENT referred to above, these two metonymic patterns, I will assume here, perfectly represent the idea that Christians are "legally justified before God by being liberated from the guilt and penalty that they should pay" (Cho 2014: 121). There is a clear contrast here between the social rejection and ostracism with which guilty people are punished and the divine acceptance of sinners through the forgiveness of their sins and the beginning of renewal.

A very similar reading can be applied to the four metaphorical mappings included in Table 8. As can be seen here, the relative number of occurrences of denominators illustrating a metaphorical understanding of guilt is much higher here than in the corpus of reference. Some of these conceptualizations of guilt, in fact, seem to be exclusively used in the Ælfrician texts, as in the case of HIDDEN OBJECT, MIXED SUBSTANCE, and BURDEN (all of which yield a number of occurrences identical or even higher than in the corpus of reference). Through these metaphors, guilt is conceptualized as an object that can be manipulated in a variety of ways: guilt can be represented as a dirty object that can be cleansed and removed, a hidden object that can be found, or as a burden that can be alleviated through Christ's redemptive work.

Table 9 illustrates the distribution of these denominators across textual types. As can be seen here, there is an apparent tendency to concentrate emotion metaphors in three textual types, namely the Saint's Lives, Religious Treatise and, especially, Homilies. Since these textual types are overrepresented in the corpus, very few conclusions can be drawn from this distribution of guilt-expressions. 
Table 9. Distribution of guilt-expressions in different textual types in the Ælfrician corpus.

\begin{tabular}{l|c|c|c|c|c|c}
\hline $\begin{array}{l}\text { TEXTUAL } \\
\text { TYPE }\end{array}$ & DEBT & CAPTIVITY & $\begin{array}{c}\text { DIRTY } \\
\text { OBJECT }\end{array}$ & $\begin{array}{c}\text { HIDDEN } \\
\text { OBJECT }\end{array}$ & $\begin{array}{c}\text { MIXED } \\
\text { SUBSTANCE }\end{array}$ & $\begin{array}{c}\text { HEAVY } \\
\text { OBJECT }\end{array}$ \\
\hline HOMILIES & 181 & 8 & 18 & 9 & 5 & 1 \\
\hline $\begin{array}{l}\text { SAINTS' } \\
\text { LIVES }\end{array}$ & 46 & - & 3 & 1 & 1 & - \\
\hline $\begin{array}{l}\text { RELIGIOUS } \\
\text { TREATISE }\end{array}$ & 37 & - & 1 & - & - & 1 \\
\hline PREFACE & 2 & - & - & - & - & - \\
\hline GLOSSES & - & - & - & - & - & - \\
\hline GRAMMAR & 13 & - & - & - & - & - \\
\hline ASTRONOMY & - & - & - & - & - & - \\
\hline TOTAL & 279 & 8 & 22 & 10 & 6 & 2 \\
\hline
\end{tabular}

Very similarly, in terms of levels of translation, Table 10 shows a higher relative incidence of guilt metaphors in texts written directly in Old English. In fact, just like in the case of shame (Table 7), guilt metaphors and metonymy are nearly exclusive of texts included in $\langle$ Lat 0$\rangle$ (with only two single occurrences in the other three categories).

Table 10. Distribution of shame-expressions across levels of translation in the Ælfrician corpus.

\begin{tabular}{l|c|c|c|c|c|c}
\hline $\begin{array}{l}\text { LEVEL OF } \\
\text { TRANSLATION }\end{array}$ & DEBT & CAPTIVITY & $\begin{array}{c}\text { DIRTY } \\
\text { OBJECT }\end{array}$ & $\begin{array}{c}\text { HIDDEN } \\
\text { OBJECT }\end{array}$ & $\begin{array}{c}\text { MIXED } \\
\text { SUBSTANCE }\end{array}$ & $\begin{array}{c}\text { HEAVY } \\
\text { OBJECT }\end{array}$ \\
\hline$<$ Lat0> & 241 & 8 & 21 & 9 & 6 & 2 \\
\hline$<$ Lat1> & 5 & - & - & 1 & - & - \\
\hline$<$ Lat2> & 29 & - & 1 & - & - & - \\
\hline$<$ Lat3> & 4 & - & - & - & - & - \\
\hline TOTAL & 279 & 8 & 22 & 10 & 6 & 2 \\
\hline
\end{tabular}

\section{Final remarks: Ælfric as an onomasiological innovator}

The main findings of this exploration of intra-writer conceptual variation patterns for shame and guilt can be summarized in the following points.

First, the distribution of shame- and guilt-metaphors in the two corpora used here clearly illustrates the very marginal character of these figurative expressions in Old English texts in general, and in Ælfrician texts in particular. As can be seen in Tables 3, 4, 5, and 8, literal denominations dominate and, in those cases where 
speakers opt for non-literal expressions, these are overwhelmingly metonymic. As previously described for Old English anger (Geeraerts \& Gevaert 2008) and fear (Díaz-Vera 2011) expressions, metaphoric conceptualizations of shame and, to a lesser extent, of guilt, are definitely peripheral.

Second, in spite of their marginality, it has been shown here that Ælfrician texts construe these two emotions figuratively much more frequently than other Anglo-Saxon writings; this is especially true for those conceptual mappings that are exclusive or nearly exclusive of this Anglo-Saxon intellectual, such as SHAME IS A LIQUID SUBSTANCE or GUILT IS A DIRTY OBJECT. As described above, in spite of their very low number of occurrences, these expressions illustrate the slow progress towards a more psychologised model of the two emotions under scrutiny here. In this sense, it can be argued here that Ælfric provides the first vernacular discourse on shame and guilt not just as social situations but, much more importantly, as psychological mechanisms of self-evaluation.

Thirdly, I have demonstrated here that, through his onomasiological choices, Ælfric combines pre-Cristian and Christian models of emotions in some of his writings: this is the case of his Saints' Lives, where two radically different construals of shame have been identified, one for the saints, who represent the gradual transformation towards the new view of these two self-assessment emotions brought to England by the Christian faith, and another for their prosecutors, which clearly reflects the dichotomy of shame and honour that characterised Germanic societies.

Finally, in terms of levels of translation, whereas texts translated from Latin tend to show a much higher number of literal denominators of shame and metonymic denominators for guilt, texts written directly in Old English tend to express these two emotions with higher degrees of figurativeness. Just like for other medieval translators and glossators, this distribution indicates Ælfric's preference to convert Latin figurative expressions into Old English literal ones. Unfortunately, given the limitations of the corpus considered here and the underrepresentation of translated texts, these results cannot be retained as conclusive.

In sum, this study has shown that, through his writings, Ælfric favoured (i) the progressive neglect of the Germanic concepts of shame and guilt as instruments of social control, (ii) the dissemination of new shame- and guilt-related values, and (iii) the growing use of a new set of conceptualizations for these two emotions, most of which have become common figurative expressions of shame and guilt in more recent varieties of English. These new expressions clearly represent the move towards a more psychologised understanding of these emotions, more in line with the new emotional standards brought by Christianization. According to these standards, rather than an external judgment or reproach, shame and guilt involve a negative evaluation of oneself. 


\section{ACKNOWLEDGEMENTS}

The present study has been supported by the Regional Government of CastillaLa Mancha (SBPLY/17/180501/000267).

\section{REFERENCES}

Bremmer, Rolf. H., Jr. 2014. Shame and honour in Anglo-Saxon hagiography, with special reference to Ælfric's Lives of Saints. In Loredana Lazzari, Patrizia Lendinara \& Claudia di Sciacca (eds.), Hagiography in Anglo-Saxon England: Adopting and adapting saints' lives into Old English prose (c.950-1150), Brepols. 95-120. DOI: 10.1484/M.TEMA-EB.4.01015

Cho, Dongsun. 2014. Divine acceptance of sinners: Augustine's doctrine of justification. Perichoresis 12(2). 163-184. DOI: 10.2478/perc-2014-0010

Constable, Giles. 1971. Twelfth-century spirituality and the late Middle Ages. Medieval and Renaissance Studies 5. 27-60.

Delumeau, Jean, 1990. Sin and fear: The emergence of the Western guilt culture, 13th-18th centuries (translated by Eric Nicholson). St. Martin's Press.

Díaz-Vera, Javier E. 2011. Reconstructing the Old English cultural model for fear. Atlantis 33(1). 85-103.

Díaz-Vera, Javier E. 2014. From cognitive linguistics to historical sociolinguistics: The evolution of Old English expressions of shame and guilt. Cognitive Linguistic Studies 1(1). 55-83. DOI: $10.1075 / \operatorname{cog} 1$ s.1.1.03dia

Díaz-Vera, Javier E. \& Teodoro Manrique-Antón. 2014. 'Better shamed before one than shamed before all': Shaping shame in Old English and Old Norse texts. In Javier E. Díaz-Vera (ed.), Metaphor and metonymy across time and cultures: Perspectives on the sociohistorical linguistics of figurative language, De Gruyter Mouton. 225-265. DOI: $10.1515 / 9783110335453.225$

Geeraerts, Dirk. 2002. The scope of diachronic onomasiology. In Vilmos Ágel, Andreas Gardt, Ulrike Haß-Zumkehr \& Thorsten Roelcke (eds.), Das Wort - Seine strukturelle und kulturelle Dimension. Festschrift für Oskar Reichmann zum 65. Geburtstag, Niemeyer. 29-44. DOI: 10.1515/9783110937596.29

Geeraerts, Dirk \& Caroline Gevaert. 2008. Hearts and (angry) minds in Old English. In Farzad Sharifian, René Dirven, Ning Yu \& Susanne Niemeyer (eds.), Culture, body, and language: Conceptualizations of internal body organs across cultures and languages, De Gruyter Mouton. 319-347. DOI: 10.1515/9783110199109.4.319

Grondelaers, Stefan \& Dirk Geeraerts, 2003. Towards a pragmatic model of cognitive onomasiology. In Hubert Cuyckens, René Dirven \& John R. Taylor (eds.), Cognitive approaches to lexical semantics, De Gruyter Mouton. 67-92. DOI: $10.1515 / 9783110219074.67$

Güldenring, Barbara Ann, 2017. Emotion metaphors in new Englishes: A corpus-based study of ANGER. Cognitive Linguistic Studies 4(1). 82-109. DOI: 10.1075/cogls.4.1.05gul

Jorgensen, Alice. 2012. 'It shames me to say it': Ælfric and the concept of vocabulary of shame. Anglo-Saxon England 41. 249-276. DOI: 10.1017/S0263675112000117 
Kahil, Rula. 2017. The complexities of 'shame': An exploration of human connection. Unpublished Ph.D. thesis: University of Toronto. https://hdl.handle.net/1807/80928

Khan, Fahad, Javier E. Díaz-Vera \& Monica Monachini. 2018. Representing meaning change in computational lexical resources: The case of shame and embarrassment terms in Old English. In Paola Cotticelli-Kurras \& Federico Giusfredi (eds.), Formal representation and the Digital Humanities, Cambridge Scholars Publishing. 59-78.

Khan, Fahad, Javier E. Díaz-Vera, Francisco Javier Minaya-Gómez, Rafael Cruz-Rodríguez \& Monica Monachini. (in press). Mapping conceptual variation through a Thesaurus of Old English and Evoke: Towards a topical thesaurus of Old English emotional expressions." Amsterdammer Beiträge zur älteren Germanistik 81.

Kleist, Aaron J., 2001. Ælfric's corpus: A conspectus. Florilegium 18(2). 113-164.

Knuuttila, Simo. 2012. The emotion of shame in medieval philosophy. SpazioFilosofico 5. 243 249.

Kövecses, Zoltán, 2000. Metaphor and emotion. Language, culture, and body in human feeling. Cambridge University Press.

Kövecses, Zoltán. 2007. Variation in metaphor. Ilha do Desterro 53. 13-39. DOI: 10.5007/\%25x

Kytö, Merja. 1996. Manual to the diachronic part of the Helsinki Corpus of English Texts: Coding conventions and lists of source texts. Department of English, University of Helsinki.

Lockett, Leslie. 2011. Anglo-Saxon psychologies in the vernacular and Latin traditions. University of Toronto Press.

Magennis, Hugh. 2005. Letter to Sigeweard. The Literary Encyclopedia. First published 15 April 2005 [https://www.litencyc.com/php/sworks.php?rec=true\&UID=16740, accessed 23/02/2021].

Musolff, Andreas. 2015. Metaphor interpretation and cultural linguistics. Language and Semiotic Studies 1(3). 35-51.

Newmark, Peter. 1988. A textbook of translation. Pearson Education Limited.

Taylor, Gabriele. 1985. Pride, shame and guilt: Emotions of self-assessment. Clarendon Press. 